\title{
Softening Hard Water using Cocoa Shell Activated Charcoal
}

\author{
*Nurhayati ${ }^{\text {a) }}$, Ahmil ${ }^{\text {(a) }}$, Khairuddin ${ }^{\text {b) }}$, Tri Handayanic) $\&$ Ahmad F. Tambuak ${ }^{\text {b) }}$ \\ a) Keperawatan - Sekolah Tingggi Ilmu Kesehatan Widya Nusantara Palu, Palu - Indonesia 94119 \\ b) Kimia/FMIPA - Universitas Tadulako, Palu - Indonesia 94119 \\ c) Teknologi Hasil Pertanian/Fakultas Pertanian - Universitas Ichsan Gorontalo, Gorontalo - Indonesia 96123 \\ Received 29 March 2021, Revised 23 April 2021, Accepted 27 May 2021 \\ doi: 10.22487/j24775185.2021.v10.i2.pp119-125
}

\begin{abstract}
Cocoa pod shells contain $23-54 \%$ cellulose, $1.14 \%$ hemicellulose, and 20-27.95\% lignin. The high cellulose content in the cocoa pod shell has the potential to be further processed into adsorbents. Before being used as an adsorbent, activation using HCl solution was carried out to increase the adsorption power of the cocoa shell. This research was conducted to analyze the influence of adsorbent dose, $\mathrm{pH}$ solution, the efficiency of hard water reduction, and adsorption capacity on $\mathrm{Ca}^{2+}$ and $\mathrm{Mg}^{2+}$ ions. Adsorption of hard water ions was conducted by varying adsorbent doses of $1,3,5,7$, and $9 \mathrm{~g}$ and varying at the $\mathrm{pH}$ of 5, 6, 7, 8, and 9. Optimum condition achieved at the mass of $5 \mathrm{~g}$ with $\mathrm{Ca}^{2+}$ and $\mathrm{Mg}^{2+}$ ions adsorption efficiency of 85.4 and $18.31 \%$, respectively. Optimum condition achieved at the pH of 9 with $\mathrm{Ca}^{2+}$ and $\mathrm{Mg}^{2+}$ ions adsorption efficiency of 61.54 and $49.11 \%$, respectively. The highest $\mathrm{Ca}^{2+}$ and $\mathrm{Mg}^{2+}$ ions adsorption capacity was obtained at the adsorbent mass of $1 \mathrm{~g}$ with adsorption capacity respectively 4.05 and $0.54 \mathrm{mg} / \mathrm{g}$. The highest $\mathrm{Ca}^{2+}$ and $\mathrm{Mg}^{2+}$ ions adsorption capacity was obtained at a $\mathrm{pH}$ of 9 with an adsorption capacity of 4.05 and $0.54 \mathrm{mg} / \mathrm{g}$, respectively.
\end{abstract}

Keywords: Hard water, adsorbent, cocoa shell, adsorption capacity

\section{Introduction}

Hard water is water that has a high content of magnesium and calcium (Padmapriya et al., 2015). Water hardness is not a problem up to the maximum recommended threshold.

The maximum limit for total hardness levels according to Permenkes RI Number 32 of 2017 concerning environmental health quality standards and water health requirements is $500 \mathrm{mg} / \mathrm{L}$ (Peraturan Menteri Kesehatan Republik Indonesia, 2017). Hardness values that exceed $500 \mathrm{mg} / \mathrm{L}$ can not be used for domestic consumption (Vermont Department of Health, 2021).

Excess minerals in water can cause problems for human health (Shahadat et al., 2015). The World Health Organization reports that excess consumption of calcium can lead to osteoporosis, cancer, hypertension, stroke, while excess consumption of magnesium results in diarrhea (Vermont Department of Health, 2021). In addition, hard water can cause the use of soap to be less foamy and the appearance of scale in the kettle (Kadir et al., 2017). The presence of a scale in the kettle or cooking utensils will cause the heat transfer to be hampered (Saeed \& Hamzah, 2013). This problem must be addressed immediately, namely by softening the hard water or water softening.
Many methods have been used to soften hard water, including the nanofiltration method (Izadpanah \& Javidnia, 2012), ion exchange (Ismail, 2016), electrolysis (Agostinho et al., 2012), electrochemistry (Zeppenfeld, 2011), and adsorption (Couto et al., 2015). Ion exchange is the method most commonly used (Kadir et al., 2017)). Although ion exchange is very effective, this technique is expensive. Adsorption is a promising method that can be used to soften hard water because of its straightforward design (Sophia \& Lima, 2018), and it can use agricultural and plantation waste (Varada, 2018). Several adsorbents have been reported to soften hard water, namely, bentonite modified with sodium dodecylbenzene sulfonate (Kadir et al., 2017), cashew skin (Varada, 2018), and almond skin (Anusha \& Kumar, 2014).

Cocoa (Theobroma cocoa) is a plantation commodity that produces the most significant proportion of fruit skin waste (Kamelia \& Fathurohman, 2017). The utilization of cocoa pod husk waste is still minimal. People use more of the waste from cocoa pods as animal feed and compost only. Most of the waste produced by cocoa pods is only left to rot around the plantation area (Purnamawati \& Utami, 2014).

Cocoa pod shells contain 23 - $54 \%$ cellulose (Masitoh \& Sianita, 2013), 1.14 \% hemicellulose,

\footnotetext{
*Correspondence:

Nurhayati

e-mail:nuha@stikeswnpalu.ac.id

(c) 2021 the Author(s) retain the copyright of this article. This article is published under the terms of the Creative Commons Attribution-NonCommercial-ShareAlike 4.0 International, which permits unrestricted non-commercial use, distribution, and reproduction in any medium, provided the original work is properly cited.
} 
and $20-27.95 \%$ lignin (Anas et al., 2011). The relatively high cellulose content in the pod husks has the potential to be further processed into adsorbents. Before being used as an adsorbent, activation can be carried out to increase the absorption power of the cocoa pods using an acid or alkaline solution. Activation with acid solutions is the most commonly used and proven effective in increasing the adsorption capacity (Purnamawati \& Utami, 2014).

\section{Methods}

\section{Equipment and materials}

The equipment used in this study was a glass funnel, a Buchner funnel, Erlenmeyer, mortar, pestle, blender, $\mathrm{pH}$ meter, 70 mesh $(212 \mu \mathrm{m})$ sieve, electromagnetic shaker, thermo shaker, astringent spoon, porcelain cup, petri dish, furnace, oven, analytical balance, equipment of titration, dropper pipette, measuring pipette, volumetric flask, desiccator, and Atomic Absorption Spectroscopy (AAS)

The materials used in this study were cocoa shells obtained from agricultural waste from cocoa farmers, $\mathrm{HCl}$ (p.a), $\mathrm{NaOH}$ (p.a), $\mathrm{Na}_{2} \mathrm{~S}_{2} \mathrm{O}_{3}$, starch, Iodine $\left(\mathrm{I}_{2}\right), \mathrm{MgCl}_{2}, \mathrm{CaCl}_{2}$, Whatman 42 paper, and distilled water.

\section{Preparation and activation of adsorbent}

The cocoa shells were cut into small pieces, then washed with water and dried. After that, the dried cocoa pods were put into a heating furnace (furnace) for the charcoal process at $600{ }^{\circ} \mathrm{C}$ for 1 hour, and then the charcoal was mashed and sieved with a 70 mesh sieve. Charcoal obtained from the sieve was chemically activated by immersing in $4 \mathrm{M}$ $\mathrm{HCl}$ solution for 24 hours and then filtered and washed using distilled water. Activated charcoal was dried in an oven at $110{ }^{\circ} \mathrm{C}$ for 5 hours and stored in a desiccator.

\section{Determination of moisture content}

$1 \mathrm{~g}$ of activated charcoal from cocoa pods and put it in a porcelain crucible, then dried in an oven at $110^{\circ} \mathrm{C}$ for 2 hours. Then the sample was put into a desiccator, then weighed until its weight was constant, and the moisture content was determined in percent (\%).

$$
\text { Water content }(\%)=\frac{a-b}{a} \times 100 \%(1)
$$

where a is the initial weight of activated carbon (g) and $\mathrm{b}$ is the weight of activated carbon after drying (g).

\section{Determination of ash content}

The moisture content of the activated charcoal from the cocoa shells was weighed as much as 0.5 grams and put into a known-weight porcelain dish. Then put it in the furnace at $600^{\circ} \mathrm{C}$ for 1 hour to form ash. Furthermore, it was cooled in a desiccator and then weighed until its weight was constant and the ash content was determined in percent (\%).

$$
\text { Ash content }(\%)=\frac{\text { weight of ash }(\mathrm{g})}{\text { weight of activated carbon }(\mathrm{g})} \times 100 \%
$$

\section{Determination of the adsorption capacity of the $I_{2}$ solution}

The activated charcoal that heated in an oven was weighed as much as $\pm 0.5 \mathrm{~g}$ and put into the Erlenmeyer. The sample was given a $50 \mathrm{~mL} 0.1 \mathrm{~N}$ iodine solution, stirred using a shaker for 15 minutes, and let stand for 15 minutes. Furthermore, $10 \mathrm{~mL}$ of filtrate was taken and titrated with $0.1 \mathrm{~N} \mathrm{Na}_{2} \mathrm{~S}_{2} \mathrm{O}_{3}$ solution. If the yellow color of the solution looks faint, then add $1 \mathrm{~mL}$ of $1 \%$ starch solution. Repeat titration until the blue color disappears.

adsorption capacity $\mathrm{I}_{2}(\mathrm{mg} / \mathrm{g})=\overline{\left(\mathrm{V}_{1} \mathrm{~N}_{1}-\mathrm{V}_{2} \mathrm{~N}_{2}\right)} \times 126,9 \times 5 \times 100 \%$

$\mathrm{V}_{1}$ is analyzed iodine solution $(\mathrm{mL}), \mathrm{N}_{1}$ is iodine normality, $\mathrm{V}_{2}$ is required thiosulfate solution $(\mathrm{mL})$, $\mathrm{N}_{2}$ is sodium thiosulfate normality, and $\mathrm{W}$ is the weight of activated charcoal $(\mathrm{g})$.

\section{Effect of adsorbent dose on adsorption of $M g^{2+}$ and $C a^{2+}$ ions}

The activated charcoal adsorbent of cocoa shells was weighted as much as $1,3,5,7$, and $9 \mathrm{~g}$, respectively, followed by the addition of the adsorbent into $50 \mathrm{~mL}$ of $100 \mathrm{ppm}$ imitation hard water, then shake with a shaker for 60 minutes. After that, it was filtered then the filtrate was analyzed for the levels of $\mathrm{Ca}^{2+}$ ions and $\mathrm{Mg}^{2+}$ ions using AAS.

\section{Effect of adsorbent $\mathrm{pH}$ on adsorption of $\mathrm{Mg}^{2+}$ and $\mathrm{Ca}{ }^{2+}$ ions}

The optimum adsorbent for activated charcoal from cocoa shells obtained from the determination of the adsorbent dose was put into an Erlenmeyer containing $50 \mathrm{~mL}$ of $100 \mathrm{ppm}$ imitation hard water at $\mathrm{pH} 5,6,7,8$, and 9. Shake the mixture using a shaker for 60 minutes. The mixture was then filtered and analyzed for the content of $\mathrm{Mg}^{2+}$ and $\mathrm{Ca}^{2+}$ metal ions using AAS.

\section{Results and Discussion}

\section{Preparation of charcoal from cocoa shells}

Before carrying out the carbonation, the cocoa shells were prepared previously, namely washing the cacao shells with clean water to minimize impurities such as soil and adhering sand. Then left the cocoa shells dry in the sun to reduce the moisture content. Dried cocoa shells were carbonized in the furnace at $600{ }^{\circ} \mathrm{C}$ for 1 hour. Furthermore, the charcoal was mashed using a mortar and pestle. The powder that had been obtained was then sieved with a 70 mesh sieve. This sieving is carried out to uniform the powder size to get a good and homogeneous particle size to increase its surface area(Maleiva et al., 2015). 


\section{Activation of charcoal}

The charcoal yield obtained from cocoa shell waste still contains impurities (Sianipar et al., 2016). The presence of contaminants that stick to the pores of charcoal, such as inorganic minerals, can affect the absorption of charcoal (Sekewael et al., 2015; Sianipar et al., 2016). The way to get rid of these impurities is by activating them. Activation is a treatment carried out on charcoal to remove contaminants that cover the pores, cause the surface area to increase, and affect its adsorption power (Setiawan et al., 2018). The manufacture of activated charcoal in this study used $4 \mathrm{M} \mathrm{HCl}$ as its activation material.

The charcoal had activated then washed with distilled water. The filtered filtrate was tested using universal indicator paper until the neutral $\mathrm{pH}$ was attained. The activated charcoal is dried in an oven at $110{ }^{\circ} \mathrm{C}$ for 5 hours. A temperature of $110{ }^{\circ} \mathrm{C}$ is to evaporate water that is still trapped in the charcoal pores.

\section{Determination of moisture content}

Determination of moisture content was to determine how much moisture content is in the activated charcoal of the cocoa shells. The high and low moisture content indicates the amount of water covering the pores of activated charcoal. The less moisture content contained in activated charcoal, the larger the pores produced. The bigger the pores of activated charcoal, the wider the surface area so that the adsorption ability of activated charcoal will be optimal (Masyithah et al., 2018).

Based on Indonesian Nasional Standard (SNI) 06-3730-1995, the permissible moisture content of activated charcoal in powder form is a maximum of $15 \%$. The moisture content obtained in this study was $4.46 \%$, meaning that the water content produced had met the standards set by SNI.

\section{Determination of ash content}

Determination of ash content aims to determine the remnants of minerals and metal oxides in activated charcoal, which are insoluble and wasted during the charring and activation processes. The ash content will affect the quality, which can cause clogging of pores to affect absorption. It happens because the surface area of the activated charcoal will decrease due to the clogging of the pores (Pandia et al., 2017).

Based on SNI 06-3730-1995, the maximum permissible ash content of activated charcoal is $10 \%$. The ash content obtained from the observations was $28.46 \%$. This figure still does not follow the standards that have been set. The high ash content obtained indicates that mineral residues in activated charcoal are not wasted during the activation process to clog the pores of activated charcoal and reduce its adsorption power.

\section{Determination of the iodine number}

Iodine adsorption is one of the main parameters used to determine the quality of activated charcoal. The reactivity of activated charcoal can see from its ability to adsorb the substrate. The adsorption power indicated the amount of iodine number, which is a number that shows how much the adsorbent can adsorb iodine. The greater the iodine number, the greater the adsorption power of the adsorbent or activated charcoal (Setyoningrum et al., 2018).

The adsorption power of activated charcoal to iodine correlates with the number of pores or the surface area of the activated charcoal. The magnitude of the absorption of activated charcoal to iodine also illustrates the many micropore structures that formed (Alzaydien, 2016).

Based on SNI 06-3730-1995, the minimum iodine adsorption is $750 \mathrm{mg} / \mathrm{g}$. The iodine number obtained from this study was $881.955 \mathrm{mg} / \mathrm{g}$; the results of this iodine adsorption have met the set standards.

Based on the results of the tests carried out to on the quality of activated charcoal, the conclusion that the moisture content, ash content, and iodine absorption capacity of activated charcoal from cocoa shells are presented in Table 1 .

Table 1. The test results of activated charcoal-based on SNI 06-3730-1995

\begin{tabular}{lll}
\hline \multicolumn{1}{c}{ Type of testing } & \multicolumn{1}{c}{ SNI 06- 3730-1995 } & Activated charcoal result \\
\hline Moisture content & Max. $15 \%$ & $4.46 \%$ \\
Ash content & Max. $10 \%$ & $28.46 \%$ \\
Iodin adsorption & Min. $750 \mathrm{mg} / \mathrm{g}$ & $881.955 \mathrm{mg} / \mathrm{g}$ \\
\hline
\end{tabular}

\section{Effect of dose on $\mathrm{Mg}^{2+}$ and $\mathrm{Ca}^{2+}$ ions adsorption}

Determination of the optimum adsorbent dose is needed to determine the adsorption efficiency of the concentration of $\mathrm{Ca}^{2+}$ and $\mathrm{Mg}^{2+}$ ions. The decrease in
$\mathrm{Ca}^{2+}$ and $\mathrm{Mg}^{2+}$ ions concentration was analyzed using AAS and calculated the adsorption efficiency. The curve of the adsorbent dose effect on the adsorption efficiency of $\mathrm{Ca}^{2+}$ and $\mathrm{Mg}^{2+}$ ions is shown in Figure 1. 


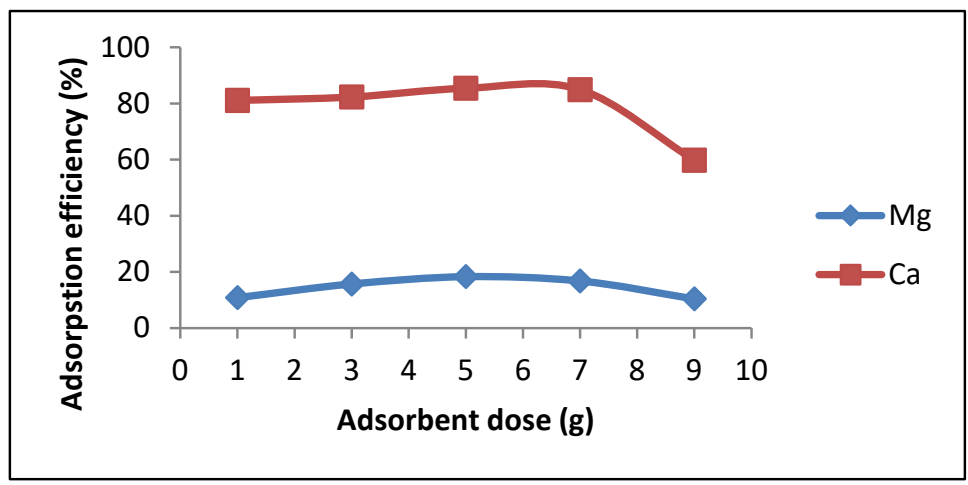

Figure 1. Adsorption efficiency curve of $\mathrm{Ca}^{2+}$ dan $\mathrm{Mg}^{2+}$ ions

Figure 1 shows that the best adsorption efficiency is found in the dose of $5 \mathrm{~g}$ with adsorption efficiency values for calcium and magnesium of $85.4 \%$ and $18.31 \%$, respectively. It can be seen that at a dose of 1 to $5 \mathrm{~g}$, there is an increase in adsorption percentage. It might be due to the increased adsorbent dose will increase the number of active sites and the surface area of the activated charcoal (Mgombezi et al., 2017), causing the adsorbent surface to bind $\mathrm{Ca}^{2+}$ ions and $\mathrm{Mg}^{2+}$ ions to increase. Furthermore, there was a decrease in the adsorption efficiency of the dose from 7 to $9 \mathrm{~g}$. It indicates that the dose of $5 \mathrm{~g}$ is the equilibrium point of the active site of the adsorbent or the saturation limit. Hence, in excess of the dose of $5 \mathrm{~g}$, the amount of activated charcoal used is no longer efficient for adsorption. This event is known as desorption. Desorption can occur if the adsorption process has reached its optimum, the adsorbent surface is saturated or is no longer able to adsorb the adsorbate, and equilibrium occurs (Giyatmi et al., 2019).
The data obtained also show that the adsorbed concentration of $\mathrm{Ca}^{2+}$ ions is far away more than the $\mathrm{Mg}^{2+}$ ion. The $\mathrm{Ca}^{2+}$ ion has a larger atomic radius than the $\mathrm{Mg}^{2+}$ ion, which causes the ionization energy to decrease. It is easy to form strong bonds on the surface of the activated charcoal.

\section{Effect of $\mathrm{pH}$ on $\mathrm{Mg}^{2+}$ and $\mathrm{Ca}^{2+}$ ions adsorption}

After obtaining the optimum dose, then determine the optimum $\mathrm{pH}$ of the activated charcoal adsorbent to determine the exact degree of acidity in adsorbing $\mathrm{Ca}^{2+}$ and $\mathrm{Mg}^{2+}$ ions in hard water. Determination of the optimum $\mathrm{pH}$ is carried out because it affects the surface charge of the adsorbent. The $\mathrm{pH}$ value is one of the most critical parameters in the adsorption process and can affect the chemical equilibrium of the adsorbate and adsorbent. This research was conducted at $\mathrm{pH}$ range $5,6,7,8$, and 9 . The effect of $\mathrm{pH}$ on the adsorption of $\mathrm{Ca}^{2+}$ and $\mathrm{Mg}^{2+}$ ions in hard water can be seen in Figure 2 .

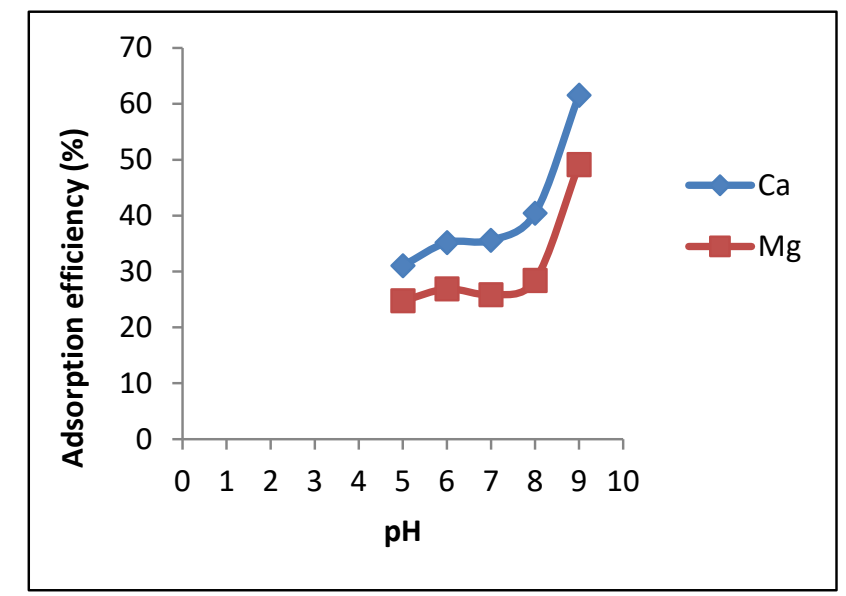

Figure 2. Adsorption efficiency curve of $\mathrm{Ca}^{2+}$ dan $\mathrm{Mg}^{2+}$ ions

Figure 2 shows that the adsorption process has increased with increasing $\mathrm{pH}$. When conditions are acidic or $\mathrm{pH}<7$, the adsorption process of $\mathrm{Ca}^{2+}$ ions and $\mathrm{Mg}^{2+}$ ions is low and increases at alkaline $\mathrm{pH}$ or $\mathrm{pH}>7$. The low adsorption efficiency of $\mathrm{Ca}^{2+}$ and $\mathrm{Mg}^{2+}$ ions at $\mathrm{pH}<7$ because when conditions are 
acidic, $\mathrm{H}^{+}$ions in solution are abundant. A large amount of proton causes competition between $\mathrm{H}^{+}$ ions with $\mathrm{Ca}^{2+}$ and $\mathrm{Mg}^{2+}$ ions on the active site of the adsorbent surface so that the attractive force between the adsorbent and the ion decrease (Mgombezi et al., 2017). When the solution is in alkaline conditions or $\mathrm{pH}>7$, the number of $\mathrm{OH}^{-}$ ions is relatively abundant in the solution, which causes the adsorbent surface to become negatively charged (Varada, 2018). It affects the adsorption of
$\mathrm{Ca}^{2+}$ and $\mathrm{Mg}^{2+}$ ions on the adsorbent surface through the electrostatic force of attraction (Mgombezi et al., 2017).

\section{Adsorption capacity of $\mathrm{Ca}^{2+}$ and $\mathrm{Mg}^{+}$ions in adsorbent dose variation}

Determination of the adsorption capacity aims to determine the number of $\mathrm{Ca}^{2+}$ and $\mathrm{Mg}^{2+}$ ions absorbed by the adsorbent, expressed in $\mathrm{mg} / \mathrm{g}$. The value of the adsorption capacity of $\mathrm{Ca}^{2+}$ ions and $\mathrm{Mg}^{2+}$ ions is listed in Table 2 .

Table 2. Adsorption capacity values on the dose variation of activated charcoal

\begin{tabular}{ccc}
\hline \multirow{2}{*}{ Dose (gram) } & \multicolumn{2}{c}{ Adsorption capacity $(\mathrm{mg} / \mathrm{g})$} \\
\cline { 2 - 3 } $\mathrm{Mg}^{2+}$ & 0.54 \\
3 & 4.05 & 0.26 \\
5 & 1.37 & 0.18 \\
7 & 0.85 & 0.12 \\
9 & 0.61 & 0.06 \\
\hline
\end{tabular}

Table 2 shows that the highest adsorption capacity of $\mathrm{Ca}^{2+}$ and $\mathrm{Mg}^{2+}$ ions were obtained at $1 \mathrm{~g}$ of adsorbent dose of $4.05 \mathrm{mg} / \mathrm{g}$ and $0.54 \mathrm{mg} / \mathrm{g}$, respectively. The lowest adsorption capacity of $\mathrm{Ca}^{2+}$ and $\mathrm{Mg}^{2+}$ ions were obtained at the adsorbent dose of $9 \mathrm{~g}$, respectively $0.23 \mathrm{mg} / \mathrm{g}$ and $0.06 \mathrm{mg} / \mathrm{g}$. The data reveal that the adsorption capacity for $\mathrm{Ca}^{2+}$ and $\mathrm{Mg}^{2+}$ ions decreased along with the increase in the dose of adsorbent.

The decrease in adsorption capacity occurs because the active site of the adsorbent is not all bound to the adsorbate. The increase in adsorption capacity is inversely proportional to the dose used. It might be due to the adsorption capacity measures the number of $\mathrm{Ca}^{2+}$ ions and $\mathrm{Mg}^{2+}$ ions adsorbed per unit weight of the adsorbent (Putri et al., 2019).

\section{Adsorption capacity of $\mathrm{Ca}^{2+}$ and Ion $\mathrm{Mg}^{2+}$ ions on pH variation}

The results of determining the adsorption capacity at various $\mathrm{pH}$ identified as shown in Table 3.

Table 3. Adsorption capacity values on $\mathrm{pH}$ variation

\begin{tabular}{clc}
\hline \multirow{2}{*}{$\mathrm{pH}$} & \multicolumn{2}{c}{ Adsorption capacity $(\mathrm{mg} / \mathrm{g})$} \\
\cline { 2 - 3 } & $\mathrm{Ca}^{2+}$ & $\mathrm{Mg}^{2+}$ \\
\hline 5 & 0.30 & 0.25 \\
6 & 0.35 & 0.27 \\
7 & 0.35 & 0.26 \\
8 & 0.40 & 0.28 \\
9 & 0.61 & 0.49 \\
\hline
\end{tabular}

Based on Table 3, the highest adsorption capacity of $\mathrm{Ca}^{2+}$ and $\mathrm{Mg}^{2+}$ ions was obtained at $\mathrm{pH}$ 9 with adsorption capacity values of $0.61 \mathrm{mg} / \mathrm{g}$ and $0.49 \mathrm{mg} / \mathrm{g}$, respectively. The lowest adsorption capacity value of $\mathrm{Ca}^{2+}$ and $\mathrm{Mg}^{2+}$ ions was at $\mathrm{pH} 5$, with adsorption capacity values of $0.3 \mathrm{mg} / \mathrm{g}$ and $0.25 \mathrm{mg} / \mathrm{g}$, respectively. Based on these data, the adsorption capacity increases with the increasing $\mathrm{pH}$ of the solution.

The largest adsorption capacity occurs at alkaline $\mathrm{pH}$ because, under these conditions, the competition between protons $\left(\mathrm{H}^{+}\right)$and metal ions $\left(\mathrm{Ca}^{2+}\right.$ and $\left.\mathrm{Mg}^{2+}\right)$ decreases on the surface of the activated charcoal so that $\mathrm{Ca}^{2+}$ ions and $\mathrm{Mg}^{2+}$ ions can readily be adsorbed on the surface of the activated charcoal (Mgombezi \& Vegi, 2020).

\section{Conclusions}

The results showed that activated charcoal from cocoa shells could adsorb $\mathrm{Ca}^{2+}$ and $\mathrm{Mg}^{2+}$ ions with hard water content. The mass and $\mathrm{pH}$ of the adsorbent affect the adsorption of $\mathrm{Ca}^{2+}$ and $\mathrm{Mg}^{2+}$ ions. The equilibrium of the adsorption process was achieved at the dose of $5 \mathrm{~g}$ and the $\mathrm{pH}$ of 9 with an adsorption capacity of $\mathrm{Ca}^{2+}$ and $\mathrm{Mg}^{2+}$ ions, respectively, $0.61 \mathrm{mg} / \mathrm{g}$ and $0.49 \mathrm{mg} / \mathrm{g}$, respectively.

\section{Acknowledgments}

Researchers would like to thank Ristek Dikti for funding this research through the Penelitian Dosen Pemula (PDP) grant program in 2019. 


\section{References}

Agostinho, L. C. L., Nascimento, L., \& Cavaicanti, B. L. (2012). Water hardness removal for industrial use: application of the electrolysis process. Journal of Cancer Science \& Therapy, 1(9), 1-5.

Alzaydien, A. S. (2016). Physical, chemical and adsorptive characteristics of local oak sawdust based activated carbons. Asian Journal of Scientific Research, 9(2), 45-56.

Anas, S., Zubair, A., \& Rohmadi, D. (2011). Kajian pemberian pakan kulit kakao fermentasi terhadap pertumbuhan sapi bali. Jurnal Agrisistem, 7(2), 79-86.

Anusha, G., \& Kumar, S. M. S. (2014). Adsorption of iron from aqueous solution using small gooseberry seeds as adsorbent. Pollution Research Paper, 30(3), 361-363.

Couto, O. M., Matos, I., da Fonseca, I. M., Arroyo, P. A., da Silva, E. A., \& de Barros, M. A. S. D. (2015). Effect of solution $\mathrm{pH}$ and influence of water hardness on caffeine adsorption onto activated carbons. Canadian Journal of Chemical Engineering, 93(January), 68-77.

Giyatmi, Sembiring, A. P., \& Putra, S. (2019). Adsorpsi logam seng pada limbah batik menggunakan pulpa kopi terxanthasi. Prosiding Seminar Nasional Kimia Dan Pembelajarannya (SNKP) 2019 (pp 192-201). Malang: Universitas Negeri Malang.

Ismail, N. N. (2016). Experimental study on ion exchange rate of calcium hardness in water softening process using strong acid resin DOWEX HCR S/S. Al-Nahrain University, College of Engineering Journal (NUCEJ), 19(1), 107-114.

Izadpanah, A. B., \& Javidnia, A. (2012). The ability of a nanofiltration membrane to remove hardness and ions from diluted seawater. Water, 4(2), 283-294.

Kadir, N. N. A., Shahadat, M., \& Ismail, S. (2017). Formulation study for softening of hard water using surfactant modified bentonite adsorbent coating. Applied Clay Science, 137(March), $168-175$.

Kamelia, M., \& Fathurohman. (2017). Pemanfaatan kulit buah kakao fermentasi sebagai altrnatif bahan pakan nabati serta pengaruhnya terhadap pertumbuhan ternak entok (Cairina muschata). Biosfer: Jurnal Tadris Biologi, 8(1), 66-77.

Maleiva, L. T. N., Sitorus, B., \& Jati, D. R. (2015). Penurunan konsentrasi gas karbon monoksida. Jurnal Kimia Khatulistiwa (JKK), 4(1), 35-42.

Masitoh, Y. F., \& Sianita, M. M. (2013). Pemanfaatan arang aktif kulit buah coklat (Theobroma cacao L.) sebagai adsorben logam berat Cd (II) dalam pelarut air. UNESA Journal of Chemistry, 2(2), 23-28.
Masyithah, C., Aritonang, B., \& Gultom, E. (2018). Pembuatan arang aktif dari limbah kulit durian sebagai adsorben pada minyak goreng bekas untuk menurunkan kadar asam lemak bebas dan bilangan peroksida. Jurnal Kimia Saintek dan Pendidikan, II(2), 66-75.

Peraturan Menteri Kesehatan Republik Indonesia. (2017). Standar baku mutu kesehatan lingkungan dan persyaratan kesehatan air untuk keperluan higiene sanitasi, kolam renang, solus per aqua dan pemandian umum. Retrieved May 18, 2020, from http://hukor.kemkes.go.id/uploads/produk_hu kum/PMK_No._32_ttg_Standar_Baku_Mutu _Kesehatan_Air_Keperluan_Sanitasi,_Kolam_ Renang,_Solus_Per_Aqua_.pdf.

Mgombezi, D., Rao, V., Vuai, S. H., \& Singh, S. K. (2017). An investigation on effectiveness of cactus materials (Opuntia spp.) as adsorbents for Hard water treatment. International Journal of Scientific \& Technology Research, 6(10), 239244.

Mgombezi, D., \& Vegi, M. R. (2020). An investigation on effectiveness of grafted potato starch as an adsorbent for hard water treatment. Journal of Chemistry, 2020, 1-11.

Padmapriya, R., Saranya, T., \& Thirunalasundari, T. (2015). Phyllanthus emblica-A biopotential for hard water treatment. International Journal of Pure \& Applied Bioscience, 3(3), 291-295.

Pandia, S., Siahaan, A. D. Y., \& Hutagalung, A. T. (2017). Pemanfaatan adsorben dari kulit buah kakao (Theobroma cacao l) untuk menurunkan chemical oxygen demand pada palm oil mill effluent. Jurnal Teknik Kimia USU, 6(3), 3440.

Purnamawati, H., \& Utami, B. (2014). Pemanfaatan limbah kulit buah kakao (Theobroma cocoa L) sebagai adsorben zat warna rhodamin B. Prosiding Seminar Nasional Fisika Dan Pendidikan Fisika (SNFPF) (pp 1218). Surakarta: Universitas Sebelas Maret.

Putri, I. D., Daud, S., \& Elystia, S. (2019). Pengaruh massa dan waktu kontak adsorben cangkang buah ketapang terhadap efisiensi penyisihan logam Fe dan zat organik pada air gambut. Jurnal Online Mahasiswa Fakultas Teknik, 6(2), 1-13.

Saeed, A., \& Hamzah, M. J. (2013). New approach for removal of total hardness $\left(\mathrm{Ca}^{2+}, \mathrm{Mg}^{2+}\right)$ from water using commercial polyacrylic acid hydrogel beads, study, and application. International Journal of Advanced Biological and Biomedical Research, 1(9), 1142-1156.

Sekewael, S. J., Latupeirissa, J., \& Johannes, R. (2015). Adsorption of Cd metal using active carbon from cacao shell (Theobroma cacao). Indonesian Journal Chemical. Research, 2(2), 197-204.

Setiawan, Y., Mahatmanti, F. W., \& Harjono. (2018). Preparasi dan karakterisasi nanozeolit 
dari zeolit alam gunungkidul dengan metode top-down. Indonesian Journal of Chemical Science, 7(1), 43-49.

Setyoningrum, T. M., Setiawan, A., \& Pamungkas, G. (2018). Pembuatan karbon aktif dari hasil pirolisis ban bekas. Eksergi: Jurnal Prodi Teknik Kimia UPN 'Veteran' Yogyakarta, 15(2), 54-58.

Shahadat, M., Teng, T. T., Rafatullah, M., \& Arshad, M. (2015). Titanium-based nanocomposite materials: A review of recent advances and perspectives. Colloids and Surfaces B: Biointerfaces, 126(February), 121-137.

Sianipar, L. D., Zaharah, T. A., \& Syahbanu, I. (2016). Adsorpsi $\mathrm{Fe}(\mathrm{II})$ dengan arang kulit buah kakao (Theobroma cacao L.) teraktivasi asam klorida. Jurnal Kimia Khatulistiwa (JKK), 5(2), 50-59.

Sophia, C., \& Lima, E. C. (2018). Removal of emerging contaminants from the environment by adsorption. Ecotoxicology and Environmental Safety, 150(April), 1-17.

Varada, K. (2018). Adsorption studies on water hardness removal by using moringa oleifera seed pod husk activated carbon as an adsorbent. International Journal of Life Sciences, Special Issue, A12, 1-8.

Vermont Department of Health. (2021) Hardness in drinking water. Retrieved May 15, 2021 from https://www.healthvermont.gov/environment/ drinking-water/hardness-drinkingwater\#:-:text $=$ The $\% 20$ membrane $\% 20$ manufa cturers $\% 20$ will\%20often,to $\% 2010 \% 20$ grains $\% 20$ per\%20gallon).

Zeppenfeld, K. (2011). Electrochemical removal of calcium and magnesium ions from aqueous solutions. Desalination, 277(1-3), 99-105. 